\title{
Evaluation of disease resistance potential of diorganotin complexes in some bacteria and fungi
}

\author{
Savita Belwal ${ }^{1}$, R. V. Singh ${ }^{2}$ \\ ${ }^{1}$ Department of Chemical Engineering, CVSR College of Engineering, Hyderabad, India \\ ${ }^{2}$ Department of Chemistry, University of Rajasthan, Jaipur 302004, India
}

\section{Email address:}

savita_gopal@rediffmail.com (S. Belwal)

\section{To cite this article:}

Savita Belwal, R. V. Singh. Evaluation of Disease Resistance Potential of Diorganotin Complexes in Some Bacteria and Fungi. Science Journal of Chemistry. Vol. 1, No. 5, 2013, pp. 67-73. doi: 10.11648/j.sjc.20130105.13

\begin{abstract}
The reaction of diphenyltin dichloride and dimethyltin dichloride with the ligands of Schiff base lead to the formation of a new series of bioactive organotin (IV) complexes. The isolated products are coloured solids soluble in most of the organic solvents. The bonding and coordination behaviour of these compounds are discussed by the support of electronic, infrared and multinuclear magnetic resonance $\left({ }^{1} \mathrm{H},{ }^{13} \mathrm{C}\right.$ and ${ }^{119} \mathrm{Sn}$ NMR) spectral studies. These investigations suggest that the ligands act in a bidentate manner, coordination through the sulphur and nitrogen atoms. Trigonal bipyramidal geometry is proved for 1:1 metal complexes and hexacoordinated geometry is assigned for 1:2 metal complexes. All the complexes are monomeric in nature as indicated by their molecular weight determinations. Conductivity measurements show them to be non-electrolyte as the conductance values in DMF lie in the range of $10-12 \mathrm{ohm}^{-1} \mathrm{~cm}^{2} \mathrm{~mol}^{-1}$. Schiff bases and their corresponding organotin complexes have also been screened for their antifungal and antibacterial activities and found to be quite active in this respect. Testing of ligands and their organotin complexes for disease resistance have been successfully studied in vitro and in vivo experiments. Results were quite encouraging and these were compared with the standard pesticides Bavistin and Streptomycin.
\end{abstract}

Keywords: Organotin (IV) Complexes, Thio- and Semi-Ligands, Spectral Studies, Biochemical Studies, Toxicity, in Vitro and in Vivo Study

\section{Introduction}

Among the metallic compounds of p-block elements that have been studied are organotin compounds. Organotins are used for industrial, agricultural and other biomedical ${ }^{1}$ applications. They are significantly more toxic than inorganic tins ${ }^{2}$. The occurrence of tin in plants, animals and in humans is discussed in relation to its abundance in the lithosphere and hydrosphere and the range of different tin (II) and tin (IV) complexes formed. A reasoned consideration of the essentiality of tin for living species is given and it is concluded that tin is beneficial element ${ }^{3}$. Trisubstituted alkyl and aryltins ( $\mathrm{R}_{3} \mathrm{Sn}$ 's $)$ while monosubstituted organotins (RSn's) are still less toxic. Among trisubstituted compounds propyl-, butyl-, pentyl-, phenyl- and cyclohexyl tin compounds are generally the most toxic to microorganisms ${ }^{4}$. Wide use of these complexes has impelled an extensive assessment of the general toxicology of these compounds. The attention in organotin (IV) compounds is due to their versatile applicability in pharmaceutical and in chemical industries. Some new organotin (IV) derivatives ${ }^{5,6}$ with general formula $\mathrm{R}_{2} \mathrm{SnL}$, where $\mathrm{R}=n$-Bu have been screened against seven cancer cell lines of human origin, viz. MCF-7, EVSA-T, WiDr, IGROV, M19, MELA498 and H226. The activity of these compounds were comparable to those of conventionl drugs i.e. methotrexate and 5- fluorouracil.

A close review of the tin in pharmaceutical application includes tin-coating antitumour agent, biomedical applications covering biochemical, agricultursl and other biocidal uses ${ }^{7}$. Organometallic compounds containing lead, tin and mercury are all commercially significant. A large number of organotin compounds are used as pharmaceuticals, pesticides and stabilizers for polyvinyl chloride and fire retardants ${ }^{8,9}$.

\section{Experimental}

\subsection{Physical Measurements}

All the chemicals were dried and purified before use and 
the reactions were carried out with a distillation assembly, fitted with condensor and protected from moisture. Nitrogen was estimated by the Kjeldahl's method and sulphur was estimated by the Messenger's method. Tin was determined gravimetrically as $\mathrm{SnO}_{2}$ with the help of silica crucible. The conductance was measured by conductivity bridge type 304 Systronics model and the molecular weights were determined by the Rast Camphor method. ${ }^{1} \mathrm{H}$ and ${ }^{19} \mathrm{~F}$ NMR spectra were recorded in DMSO- $\mathrm{D}_{6},{ }^{13} \mathrm{C}$ and ${ }^{119} \mathrm{Sn}$ spectra were recorded in methanol, using TMS as the internal standard. $\mathrm{C}_{6} \mathrm{~F}_{6}$ was used as the external reference for the ${ }^{19} \mathrm{~F}$ NMR spectra and tetramethyl tin is used as external reference for ${ }^{119} \mathrm{Sn}$ NMR spectra. IR spectra were recorded on FTIR spectrophotometer, model IR-550 as nujol mulls using $\mathrm{KBr}$ optics.

\subsection{Synthesis of the Ligands, $L_{1} H$ and $L_{2} H$}

Ligand $\left(\mathrm{L}_{1} \mathrm{H}\right)$ was prepared by the condensation of heterocyclic ketone 1,3-dihydro-3 [2-(4-fluoro-3methylphenyl)-2-oxo-ethylidene]2H-indol-2-one $\quad(5.5 \mathrm{~g})$ with hydrazinecarboxamide $(1.47 \mathrm{~g})$ in the presence of sodium acetate in equimolar ratio $(1: 1)$ in absolute alcohol.

Table 1. Physical properties of the ligands and their organotin (IV) complexes

\begin{tabular}{|c|c|c|c|c|c|c|c|c|}
\hline \multirow[t]{2}{*}{ Compound } & \multirow[t]{2}{*}{ Colour and state } & \multirow[t]{2}{*}{ Molar ratio } & \multirow[t]{2}{*}{ M.P. $\left({ }^{\circ} \mathrm{C}\right)$} & \multicolumn{5}{|c|}{ Analysis (\%) Found (Calcd.) } \\
\hline & & & & $\mathbf{C}$ & $\mathbf{H}$ & $\mathbf{N}$ & $\mathbf{S}$ & Sn \\
\hline $\begin{array}{c}\mathrm{L}_{1} \mathrm{H} \\
\mathrm{C}_{18} \mathrm{H}_{15} \mathrm{~N}_{4} \mathrm{O}_{2} \mathrm{~F}\end{array}$ & $\begin{array}{l}\text { Orange } \\
\text { Solid }\end{array}$ & & $159-160$ & $\begin{array}{c}63.60 \\
(63.96)\end{array}$ & $\begin{array}{c}4.31 \\
(4.47)\end{array}$ & $\begin{array}{c}16.48 \\
(16.58)\end{array}$ & - & - \\
\hline $\begin{array}{c}\mathrm{Me}_{2} \mathrm{SnCl}\left(\mathrm{L}_{1}\right) \\
\mathrm{C}_{20} \mathrm{H}_{20} \mathrm{~N}_{4} \mathrm{O}_{2} \mathrm{FClSn}\end{array}$ & Brown solid & $1: 1$ & $151-152$ & $\begin{array}{c}45.89 \\
(46.02)\end{array}$ & $\begin{array}{c}3.72 \\
(3.86)\end{array}$ & $\begin{array}{c}10.68 \\
(10.73)\end{array}$ & - & $\begin{array}{l}22.63 . \\
(22.74)\end{array}$ \\
\hline $\begin{array}{c}\mathrm{Me}_{2} \mathrm{Sn}\left(\mathrm{L}_{1}\right)_{2} \\
\mathrm{C}_{38} \mathrm{H}_{34} \mathrm{~N}_{8} \mathrm{O}_{4} \mathrm{~F}_{2} \mathrm{Sn}\end{array}$ & Light brown solid & $1: 2$ & $157-158$ & $\begin{array}{c}55.21 \\
(55.46)\end{array}$ & $\begin{array}{c}4.09 \\
(4.16)\end{array}$ & $\begin{array}{c}13.51 \\
(13.62)\end{array}$ & - & $\begin{array}{c}14.23 \\
(14.42)\end{array}$ \\
\hline $\begin{array}{c}\mathrm{Ph}_{2} \mathrm{SnCl}\left(\mathrm{L}_{1}\right) \\
\mathrm{C}_{30} \mathrm{H}_{24} \mathrm{~N}_{4} \mathrm{O}_{2} \mathrm{FClSn}\end{array}$ & Wine red solid & $1: 1$ & $147-148$ & $\begin{array}{c}55.71 \\
(55.78)\end{array}$ & $\begin{array}{c}3.69 \\
(3.74)\end{array}$ & $\begin{array}{c}8.56 \\
(8.67)\end{array}$ & - & $\begin{array}{c}18.58 \\
(18.37)\end{array}$ \\
\hline $\begin{array}{c}\mathrm{Ph}_{2} \mathrm{Sn}\left(\mathrm{L}_{1}\right)_{2} \\
\mathrm{C}_{48} \mathrm{H}_{38} \mathrm{~N}_{8} \mathrm{O}_{4} \mathrm{~F}_{2} \mathrm{Sn}\end{array}$ & Peech solid & $1: 2$ & $159-160$ & $\begin{array}{c}60.71 \\
(60.82)\end{array}$ & $\begin{array}{c}3.95 \\
(4.04)\end{array}$ & $\begin{array}{c}11.68 \\
(11.82)\end{array}$ & - & $\begin{array}{c}12.49 \\
(12.52)\end{array}$ \\
\hline $\begin{array}{c}\mathrm{L}_{2} \mathrm{H} \\
\mathrm{C}_{18} \mathrm{H}_{15} \mathrm{~N}_{4} \mathrm{OSF}\end{array}$ & Orange solid & & $164-165$ & $\begin{array}{c}60.82 \\
(61.07)\end{array}$ & $\begin{array}{c}4.19 \\
(4.27)\end{array}$ & $\begin{array}{c}15.72 \\
(15.83)\end{array}$ & $\begin{array}{c}9.01 \\
(9.06)\end{array}$ & - \\
\hline $\begin{array}{c}\mathrm{Me}_{2} \mathrm{SnCl}\left(\mathrm{L}_{2}\right) \\
\mathrm{C}_{20} \mathrm{H}_{20} \mathrm{~N}_{4} \mathrm{OSFClSn}\end{array}$ & Red solid & $1: 1$ & $171-172$ & $\begin{array}{c}44.01 \\
(44.65)\end{array}$ & $\begin{array}{c}3.61 \\
(3.75)\end{array}$ & $\begin{array}{c}10.32 \\
(10.41)\end{array}$ & $\begin{array}{c}5.82 \\
(5.96)\end{array}$ & $\begin{array}{c}22.01 \\
(22.06)\end{array}$ \\
\hline $\begin{array}{c}\mathrm{Me}_{2} \mathrm{Sn}\left(\mathrm{L}_{2}\right)_{2} \\
\mathrm{C}_{38} \mathrm{H}_{34} \mathrm{~N}_{8} \mathrm{O}_{2} \mathrm{~S}_{2} \mathrm{~F}_{2} \mathrm{Sn}\end{array}$ & Red solid & $1: 2$ & $175-176$ & $\begin{array}{c}53.20 \\
(53.32)\end{array}$ & $\begin{array}{c}3.85 \\
(4.00)\end{array}$ & $\begin{array}{c}13.02 \\
(13.09)\end{array}$ & $\begin{array}{c}7.41 \\
(7.49)\end{array}$ & $\begin{array}{c}13.56 \\
(13.87)\end{array}$ \\
\hline $\begin{array}{c}\mathrm{Ph}_{2} \mathrm{SnCl}\left(\mathrm{L}_{1}\right) \\
\mathrm{C}_{30} \mathrm{H}_{24} \mathrm{~N}_{4} \mathrm{OSFClSn}\end{array}$ & Wine red solid & $1: 1$ & $181-182$ & $\begin{array}{c}54.29 \\
(54.43)\end{array}$ & $\begin{array}{c}3.51 \\
(3.65)\end{array}$ & $\begin{array}{c}4.32 \\
(4.46)\end{array}$ & $\begin{array}{c}4.29 \\
(4.84)\end{array}$ & $\begin{array}{c}17.81 \\
(17.93)\end{array}$ \\
\hline $\begin{array}{c}\mathrm{Ph}_{2} \mathrm{Sn}\left(\mathrm{L}_{2}\right)_{2} \\
\mathrm{C}_{48} \mathrm{H}_{38} \mathrm{~N}_{8} \mathrm{O}_{2} \mathrm{~S}_{2} \mathrm{~F}_{2} \mathrm{Sn}\end{array}$ & Red solid & $1: 2$ & $187-188$ & $\begin{array}{c}58.75 \\
(58.83)\end{array}$ & $\begin{array}{c}3.79 \\
(3.91)\end{array}$ & $\begin{array}{c}11.35 \\
11.43)\end{array}$ & $\begin{array}{c}6.42 \\
(6.54)\end{array}$ & $\begin{array}{c}12.01 \\
(12.11)\end{array}$ \\
\hline
\end{tabular}

Ligand $\left(\mathrm{L}_{2} \mathrm{H}\right)$ was prepared by the condensation of $1,3-$ dihydro-3-[2-( 4-fluoro-3-methylphenyl)-2-oxoethylidene]-2H-indol-2-one (6.7g) with hydrazinecarbothioamide $(2.17 \mathrm{~g})$ in $1: 1$ molar ratio in alcoholic medium. These mixtures were heated under reflux for 45 minutes. The solvent was then removed and the residue was dried in vacuum under reduced pressure. The products were purified by recrystallization from the same solvent. The analysis and physical properties of these ligands are enlisted in (Table-1).

\subsection{Synthesis of the Complexes}

A calculated amount of the sodium salt of the ligand in dry methanol was added to the weighed amounts of $\mathrm{Me}_{2} \mathrm{SnCl}_{2}$ and $\mathrm{Ph}_{2} \mathrm{SnCl}_{2}$ in a round bottom flask in 1:1 and 1:2 molar ratios. The reaction was refluxed over a ratiohead for 16-18 hours and the white precipitate of sodium chloride obtained, was removed. Compounds were dried under reduced pressure for 3-4 hours. These were purified by repeated washing with $n$-hexane and methanol. All the compounds were isolated as powdered solids. The details of these reactions and the analysis of the resulting products are recorded in (Table 2). 
Table 2. ${ }^{1} H$ NMR spectra data of the ligands and their organotin (IV) complexes

\begin{tabular}{|c|c|c|c|c|c|c|c|c|}
\hline Compound & -NH ring(bs) & $-\mathrm{NH}$ free(bs) & $-\mathrm{NH}_{2}$ (bs) & $\begin{array}{l}=\mathrm{CH}-\mathrm{C}=\mathrm{N} \\
\text { (s) }\end{array}$ & $\begin{array}{l}\text { Aromatic } \\
\text { (indole ring) (m) }\end{array}$ & Sn-Me & $\begin{array}{l}\mathrm{CH}_{3}-\mathrm{Ph} \\
\text { (s) }\end{array}$ & $\begin{array}{l}\text { Aromatic } \\
\left(\mathrm{CH}_{3}-\mathrm{Ph}\right)(\mathrm{m})\end{array}$ \\
\hline $\mathrm{L}_{1} \mathrm{H}$ & 10.12 & 10.08 & 2.98 & 8.08 & $7.68-6.65$ & - & 2.25 & $7.38-7.01$ \\
\hline $\mathrm{Me}_{2} \mathrm{SnCl}\left(\mathrm{L}_{1}\right)$ & 10.24 & - & 3.12 & 8.24 & $7.84-6.72$ & $\begin{array}{l}0.98 \\
{ }^{2} J[65.2]\end{array}$ & 2.31 & $7.45-7.32$ \\
\hline $\mathrm{Me}_{2} \mathrm{Sn}\left(\mathrm{L}_{1}\right)_{2}$ & 10.28 & - & 3.16 & 8.28 & $8.08-6.94$ & $\begin{array}{l}1.04 \\
{ }^{2} J[69.0]\end{array}$ & 2.45 & $7.90-7.40$ \\
\hline $\mathrm{L}_{2} \mathrm{H}$ & 11.12 & 10.04 & 2.64 & 8.12 & $7.72-6.34$ & - & 2.29 & $7.40-7.25$ \\
\hline $\mathrm{Me}_{2} \mathrm{SnCl}\left(\mathrm{L}_{2}\right)$ & 11.24 & - & 2.70 & 8.32 & $8.24-6.68$ & $\begin{array}{l}1.08 \\
{ }^{2} J[66.5]\end{array}$ & 2.35 & $7.95-7.54$ \\
\hline $\mathrm{Me}_{2} \mathrm{Sn}\left(\mathrm{L}_{2}\right)_{2}$ & 11.30 & - & 2.72 & 8.40 & $8.34-6.64$ & $\begin{array}{l}1.14 \\
{ }^{2} J[69.5]\end{array}$ & 2.50 & $8.12-7.73$ \\
\hline
\end{tabular}

\section{Results and Discussion}

Reactions of organotin (IV) halides with monobasic bidentate ligands in 1:1 and 1:2 molar ratios in methanol may be represented by the following equations:

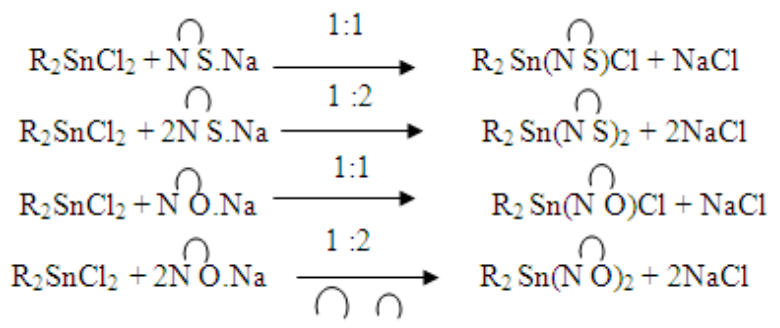

(where, $\mathrm{R}=\mathrm{Me}$ or $\mathrm{Ph} ; \mathrm{N} \mathrm{S}$ and $\mathrm{N} \mathrm{O}=$ donar set of the ligands)

\subsection{IR Spectra}

The infrared spectra of the ligands and their tin complexes were recorded and important features may be summarized as follows:

The IR spectra of fluorohydrazines show two sharp bands around 3450 and $3350 \mathrm{~cm}^{-1}$ due to vasym and vsym $\mathrm{NH}_{2}$ vibrations, respectively, which remain almost at the same positions in the metal complexes, showing noninvolvement of this group in the complexation.

The bands of medium intensity appearing in the region $3300 \mathrm{~cm}^{-1}$ and $2700 \mathrm{~cm}^{-1}$ may be assigned to $v \mathrm{NH}^{\mathbf{1 0}}$ and $v \mathrm{SH}$ vibrations, respectively, which suggest that the ligands exist as in keto-enol tautomerism. These disappear in the corresponding silicon complexes.

The band due to $>\mathrm{C}=\mathrm{N}$ of free azomethine group in the ligand get shifted to the lower wave number $(\Delta v=15-20$ $\mathrm{cm}^{-1}$ ) in the silicon complexes indicating coordination through azomethine nitrogen ${ }^{\mathbf{1 1}}$. The $v \mathrm{C}=\mathrm{O}$ band in hydrazinecarboxamide and $v \mathrm{C}=\mathrm{S}$ in hydrazinecarbothioamide appear at $1690 \mathrm{~cm}^{-1}$ and $1035 \mathrm{~cm}^{-1}$, respectively. These bands disappear on complexation, which is due to the covalent bond formation of the ligand with the silicon atom through the oxygen or sulphur atoms.
Several new bands in the complexes at 530, 420 and 325 $\mathrm{cm}^{-1}$, are due to $v(\mathrm{Sn}-\mathrm{O}), v(\mathrm{Sn} \longleftarrow \mathrm{N})$ and $v(\mathrm{Sn}-\mathrm{S})$ respectively, which are absent in the spectrum of the ligand, further supporting the participation of the sulphur atom and the azomethine nitrogen in complexation.

\subsection{UV Spectra}

A band due to the $>\mathrm{C}=\mathrm{N}$ chromophore in the spectrum of the ligand at $365 \mathrm{~nm}$ shifts to a higher wavelength in the tin complexes. This clearly indicates the coordination of the azomethine nitrogen to the tin atom. Such a shift in $n-\pi *$ transition band is probably due to the donation of lone pair of electrons by the nitrogen of the flouro-ligand to the central metal atom indicating the delocalization of the electronic charge within the chetate ring and thus stabilizing of the resulting complexes. Further, two bands at $260 \mathrm{~nm}$ and $305 \mathrm{~nm}$ are due to $\pi-\pi *$ transitions, these are assigned to the benzenoid ring and $(>\mathrm{C}=\mathrm{N})$ band of the azomethine group respectively. The $\mathrm{K}$ band $\pi-\pi *$ showed a red shift due to the overlap of the central metal d-orbital with the p-orbital of the donor atom, which causes an increase in conjugation and the B-band undergoes a hypsochromic shift in the complexes.

\section{3. ${ }^{1}$ H NMR Spectra}

The proton magnetic resonance spectra ${ }^{\mathbf{1 2}}$ of the ligands and their corresponding tin complexes were recorded in DMSO- $\mathrm{d}_{6}$ using TMS as the internal standard. The chemical shift values $(\delta, \mathrm{ppm})$ of the different protons are given in (Table 2). The ${ }^{1} \mathrm{H}$ NMR spectra of the ligands exhibit peaks around of $\delta$ value $11.24-10.12(1 \mathrm{H})$ were charecteristic of $-\mathrm{NH}$ of the isatin ring. The peaks found around $\delta$ value $7.74-6.36(7 \mathrm{H})$ may be due to aromatic protons, while that observed at $\delta$ value $10.08-10.04(1 \mathrm{H})$ due to $-\mathrm{NH}$ of thiosemicarbazone/semicarbazone. The disappearance of signal which is due to $-\mathrm{NH}$ of thiosemicarbazone/semicarbazone in the tin derivatives indicate the coordination of the azomethine nitrogen atom as well as covalent bond formation between tin and sulphur/oxygen due to deprotonation of the ligands. In the 
spectra of the complexes, a downfield shift in the position of $-\mathrm{CH}_{3}$ and aromatic protons indicate deshielding, as well as the coordination of azomethine nitrogen to the tin atom. This is probably due to the donation of the lone pair of electrons by the nitrogen to the central tin atom, resulting in the formation of a coordinate linkage $(\mathrm{Sn}-\mathrm{N})$. The appearance of a signal around $2.98-2.56 \delta$ value due to $-\mathrm{NH}_{2}$ group at the same positions in the ligand and its tin complexes, showing non-involvement of this group in coordination. A peak was observed at $\delta$ value $2.46(3 \mathrm{H})$ due to $-\mathrm{CH}_{3}$ protons attached to the phenyl ring. Further new signals at $\delta 0.98(6 \mathrm{H})$ to $\delta 1.14(6 \mathrm{H}) \mathrm{ppm}$ are due to in the $1: 1$ and $1: 2$ complexes the dimethyl protons of the tin group The ${ }^{2} J\left[{ }^{1} \mathrm{H},{ }^{119} \mathrm{Sn}\right]$ values for various compounds indicate that the compounds $\mathrm{Me}_{2} \mathrm{SnCl}\left(\mathrm{L}_{1}\right)$ and $\mathrm{Me}_{2} \mathrm{SnCl}\left(\mathrm{L}_{2}\right)$ has a 5coordinated environment ${ }^{13}$ while $\mathrm{Me}_{2} \mathrm{Sn}\left(\mathrm{L}_{2}\right)_{2}$ and $\mathrm{Me}_{2} \mathrm{Sn}\left(\mathrm{L}_{1}\right)_{2}$ show higher coordination number ${ }^{14}$, i.e. six.

\section{4. ${ }^{13}$ C NMR Spectra}

The ${ }^{13} \mathrm{C}$ NMR spectra of the ligands and their corresponding tin complexes were also recorded in dry $\mathrm{MeOH}$. Considerable shifts in the positions of carbon atoms attached to the azomethine nitrogen, thiolic sulphur or amido oxygen support the proposed coordination in these complexes. The heterocyclic moiety carbon signals, especially those of the carbon atoms directly bonded to the heteroatom, undergo slight upfield shifts relative to the other carbon atoms which remain almost undisturbed. The shift towards upfield in the signal of the thiolo carbon and azomethine carbon in the complexes suggest participation of these groups in coordination to the tin atom. The heteronuclear coupling constant values viz ${ }^{1} J\left[{ }^{13} \mathrm{C},{ }^{119} \mathrm{Sn}\right],{ }^{2} J$ $\left[{ }^{13} \mathrm{C},{ }^{119} \mathrm{Sn}\right]$ and ${ }^{3} J\left[{ }^{13} \mathrm{C},{ }^{119} \mathrm{Sn}\right]$ for few compounds are also given which are very useful in providing the information regarding the geometry ${ }^{\mathbf{1 5}} \mathbf{1 6}^{\mathbf{1 6}}$ of organotin complexes. The different $\delta$ values of all the carbon atoms of aromatic and phenyl group along with $\left(\mathrm{Sn}-\mathrm{CH}_{3}\right)^{17}$ and $\left(\mathrm{Sn}-\mathrm{C}_{6} \mathrm{H}_{5}\right)^{\mathbf{1 8 , 1 9}}$ signals are enlisted in (Table 3and 4).

Table 3. ${ }^{13} \mathrm{C}$ NMR spectra data of the ligands and their organotin (IV) complexes

\begin{tabular}{|c|c|c|c|c|c|c|}
\hline \multirow[t]{2}{*}{ Compound } & \multicolumn{6}{|c|}{ Chemical Shift Values $(\delta, \mathrm{ppm})$} \\
\hline & Amido & Azomethine & $-\mathrm{NH}-\mathrm{C}=\mathrm{O}$ & $\begin{array}{l}\text { Aromatic* } \\
\text { (indole ring) }\end{array}$ & Sn-Me/Ph & $\begin{array}{l}\text { Phenyl ring * } \\
\left(\mathrm{Ph}_{-} \mathrm{CH}_{3}\right)\end{array}$ \\
\hline $\mathrm{L}_{1} \mathrm{H}$ & 170.20 & 160.24 & 159.98 & $\begin{array}{l}143.66,140.22,127.85,123.32 \\
122.36,117.32,120.66,140.66\end{array}$ & - & $\begin{array}{l}138.1,129.9 \\
128.5,132.5 \\
130.5\end{array}$ \\
\hline $\mathrm{Me}_{2} \mathrm{SnCl}\left(\mathrm{L}_{1}\right)$ & 165.36 & 155.38 & 158.68 & $\begin{array}{l}146.32,142,01,128.98 \\
127.08,125.25,119.52 \\
123.58,141,56\end{array}$ & 16.38 & $\begin{array}{l}139.11,130.19 \\
129.25,133.15 \\
131.35\end{array}$ \\
\hline $\mathrm{L}_{2} \mathrm{H}$ & 172.52 & 155.12 & 164.58 & $\begin{array}{l}147.24,144.28,135.72, \\
130.22,129.71,120.55,121.56 \\
136.92\end{array}$ & - & $\begin{array}{l}139.91,130.95 \\
129.5,134.5 \\
131.85\end{array}$ \\
\hline $\mathrm{Ph}_{2} \mathrm{Sn}\left(\mathrm{L}_{2}\right)_{2}$ & 170.35 & 152.88 & 163.96 & $\begin{array}{l}148.94,146.12,136.01 \\
132.42,131.02,122.18,124.72, \\
138.52\end{array}$ & $\begin{array}{l}131.18,134.18 \\
135.56,138.86\end{array}$ & $\begin{array}{l}140.11,131.12 \\
129.95,135.05 \\
132.15\end{array}$ \\
\hline
\end{tabular}

Table 4. * Detailed Values of aromatic and phenyl carbons are given in below table 4.

\begin{tabular}{llllllllllllll}
\hline Compound & $\mathrm{C}_{2}$ & $\mathrm{C}_{3}$ & $\mathrm{C}_{4}$ & $\mathrm{C}_{5}$ & $\mathrm{C}_{6}$ & $\mathrm{C}_{7}$ & $\mathrm{C}_{8}$ & $\mathrm{C}_{9}$ & $\mathrm{C}_{10}$ & $\mathrm{C}_{11}$ & $\mathrm{C}_{12}$ & $\mathrm{C}_{13}$ & $\mathrm{C}_{14}$ \\
\hline $\mathbf{L}_{1} \mathbf{H}$ & 143.66 & 140.22 & 127.85 & 123.32 & 122.36 & 117.23 & 120.66 & 140.66 & 138.9 & 140.2 & 131.0 & 130.8 & 131.5 \\
$\mathbf{M e} \mathbf{S n C l}\left(\mathbf{L}_{1}\right)$ & 146.32 & 142.01 & 128.98 & 127.08 & 125.25 & 119.52 & 123.58 & 141,56 & 139.11 & 130.19 & 129.25 & 133.15 & 131.35 \\
$\mathbf{L}$ & 147.24 & 144.28 & 135.72 & 136.22 & 129.71 & 120.55 & 121.56 & 136.92 & 139.6 & 141.0 & 131.0 & 130.8 & 130.9 \\
$\mathbf{P h}_{2} \mathbf{S n}\left(\mathbf{L}_{2}\right)_{2}$ & 148.94 & 146.12 & 136.01 & 132.42 & 131.02 & 122.18 & 124.72 & 138.52 & 140.11 & 131.12 & 129.95 & 135.05 & 132.15 \\
\hline
\end{tabular}

\section{5. ${ }^{19}$ F NMR Spectra}

The ${ }^{19} \mathrm{~F}$ NMR spectrum of the ligand $\mathrm{L}_{2} \mathrm{H}$ displays a sharp singlet at $\delta-114.36 \mathrm{ppm}$. The organotin (IV) complexes of this ligand show no change in the position of the signal and thus supporting the noninvolvement of fluorine in complexation.

\section{6. ${ }^{119}$ Sn NMR Spectra}

In the case of the tin complexes $\mathrm{Ph}_{2} \mathrm{SnCl}\left(\mathrm{L}_{1}\right)$ and $\mathrm{Me}_{2} \mathrm{Sn}\left(\mathrm{L}_{2}\right)_{2}$ signals at $\delta-140.16 \mathrm{ppm}$ and $\delta-216.58 \mathrm{ppm}$ for $1: 1$ and 1:2 complexes, respectively which stated for coordination number five $\mathrm{e}^{20,21}$ and $\mathrm{six}^{22}$ around the tin atom.

On the basis of the above spectral studies, possible trigonal bipyramidal geometries for pentacoordinated state and octahedral geometries for hexacoordinated state have been suggested for 1:1 and 1:2 metal complexes (Figure 2). 

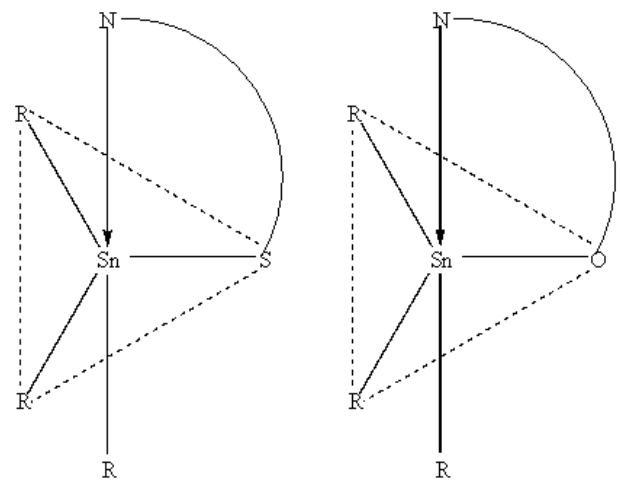

Figure 2. Suggested structures for the complexes; $R=$ Me or Ph and $\cap$ S and $\mathrm{NO}_{\mathrm{O}}=$ donar set of the ligands)

\section{Microbial Assay}

Bioefficacies of the ligands and their compounds were tested in in vitro as, well as in in vivo using the paper disc method $^{23}$ for antibacterial activity and the percent disease incidence (PDI) ${ }^{\mathbf{2 4 , 2 5}}$ for antifungal screening.

\subsection{Antibacterial Activity (in vitro)}

The organisms selected for this study are Staphylococcus aureus(+) and Escherichia coli (-) and technique used is paper disc method. In this technique sterilized hot nutrient agar and $5 \mathrm{~mm}$ diameter paper disc of Whatman No.1 were used. The agar medium was poured in the petri plates. After solidification, the plates were stored in inverted position so that there was condensation of water in upper lid. Now bacterial suspension was uniformly spread on solidified nutrient agar. The solutions of test compounds in methanol (500 and $1000 \mathrm{ppm}$ concentrations) were prepared, in which discs were dipped and placed on petri plates. The petri plates having these discs on the seeded agar should be placed at low temperature for two or four hours to allow for the diffusion of chemical before being incubated at suitable optimum temperature $\left(28+2{ }^{0} \mathrm{C}\right)$ for $24-30$ hours and the inhibition zone around each disc was measured and reported in (Table 5).

Table 5. Bactericidal screening data of the ligands and their Tin complexes

\begin{tabular}{|c|c|c|c|c|}
\hline \multirow{3}{*}{ Compound } & \multicolumn{4}{|c|}{ Diameter of inhibition zone (mm) } \\
\hline & \multicolumn{2}{|c|}{$\begin{array}{l}\text { Staphylococcus aureus }(+) \\
(\text { Concentration in } \mathrm{ppm})\end{array}$} & \multicolumn{2}{|c|}{$\begin{array}{l}\text { Escherichia coli (-) } \\
\text { (Concentration in ppm) }\end{array}$} \\
\hline & 500 & 1000 & 500 & 1000 \\
\hline $\mathrm{L}_{1} \mathrm{H}$ & 8 & 11 & 6 & 10 \\
\hline $\mathrm{Me}_{2} \mathrm{SnCl}\left(\mathrm{L}_{1}\right)$ & 12 & 16 & 10 & 12 \\
\hline $\mathrm{Me}_{2} \mathrm{Sn}\left(\mathrm{L}_{1}\right)_{2}$ & 14 & 17 & 13 & 15 \\
\hline $\mathrm{L}_{2} \mathrm{H}$ & 9 & 12 & 7 & 11 \\
\hline $\mathrm{Ph}_{2} \mathrm{SnCl}\left(\mathrm{L}_{2}\right)$ & 13 & 16 & 10 & 14 \\
\hline $\mathrm{Ph}_{2} \mathrm{Sn}\left(\mathrm{L}_{2}\right)_{2}$ & 16 & 19 & 12 & 16 \\
\hline Streptomycin & 15 & 17 & 17 & 18 \\
\hline
\end{tabular}

\subsection{Antifungal Activity (in vivo)}

Plant diseases play an important role in determining the amount and cost of food. Diseases caused by fungi are a major threat to profitable production. Plant pathology must alleviate the food problem by devising new central measures and improve the older ones. The chemicals, found most effective against fungal and bacterial strains which were tested in in vitro, were also tested in field for controlling the Guar blight in Guar (Cyamopsis tetragonoloba) caused by Alternaria cyamopsidae.

Field experiments were laid out in randomized block design plots with three replications. The crops (20 plants) were raised in each plot. Compounds with a standard fungicide, Bavistin, [2-(methoxycarbamyl) benzimidazole] were tried. After sowing of 45 days, the plants were inoculated artificially by spraying the conidial suspension. The suspension was prepared by crushing the infected leaves in water. The first spray of the respective fungicide was given, when lesions were first seen and were repeated after ten days. Disease intensity was analysed for statistical significance and (\%) disease control on test compounds was worked out.

$$
\text { PDI }=\frac{\text { Sum of score of infected plants } \mathrm{x} 100}{\text { Total number of plants observed } \mathrm{x} \text { Maximum rating of score (10) }}
$$

The effectiveness of the chemicals were calculated using the following formula

$$
\% \text { Disease control }=\frac{\text { PDI in treated plants }- \text { PDI in untreated plants }}{\text { PDI in untreated plants }} \times 100
$$

The results of these findings are given in (Table 6). 
Table 6. Efficacy of the compounds against Guar blight was evaluated using the Percent Disease Incidence Technique (PDI).

\begin{tabular}{lll}
\hline Compound & PDI in treated plants & \% Disease control \\
\hline $\mathrm{L}_{1} \mathrm{H}$ & 12 & 57.1 \\
$\mathrm{Me}_{2} \mathrm{SnCl}\left(\mathrm{L}_{1}\right)$ & 9 & 67.8 \\
$\mathrm{Me}_{2} \mathrm{Sn}\left(\mathrm{L}_{1}\right)_{2}$ & 8 & 71.4 \\
$\mathrm{~L}_{2} \mathrm{H}$ & 11 & 60.7 \\
$\mathrm{Ph}_{2} \mathrm{SnCl}\left(\mathrm{L}_{2}\right)$ & 5 & 82.1 \\
$\mathrm{Ph}_{2} \mathrm{Sn}\left(\mathrm{L}_{2}\right)_{2}$ & 4 & 85.7 \\
Bavistin & 3 & 89.3 \\
\hline
\end{tabular}

\subsection{Mode of Action}

Metal based fungicides inhibit a wide range of enzymes involved in various metabolic pathways, ultimately causing cell death. Early work on the mode of action of fungicides showed that these compounds inhibit cell division. It was later $^{26}$ shown that the specific site of action is $\beta$-tubuline, a polymeric protein found in microtubules - an essential component of the cytoskeleton. Phenyl and amine groups in the complexes affect nucleic acid, synthesis and mitochondrial electron transport also.

Most of the fungi contain chitin, (a homopolymer of $\beta$ 1,4-linked $\mathrm{N}$-acetyl-glucosamine, as a major component of their cell walls. All the plants have been shown to produce chitinases and an another compound, $\beta$-1,3-glucanase associated with defense system of the plants against chitin containing pathogens ${ }^{27,28}$.

We might then expect at least the following regulatory processes to be operative ${ }^{29}$.

(i) Carbon catabolic regulation ${ }^{30}$ : During the periods of rapid utilization of the carbon source, particularly of glucose or sucrose, either the formation of enzymes in the secondary metabolic pathways leading to toxins would be repressed, or the activity of these pathways would be inhibited.

(ii) Nitrogen catabolic despotism ${ }^{31}$ : Excessive levels of rapidly assimilated forms of nitrogen (e.g., ammonium ion) could repress the formation of enzymes concerned with nitrogen transformation of toxins intermediates.

(iii) Energy charge regulation: High phosphate levels could reduce the availability of high energy phosphate (i.e. ATP and ADP). This would effectively inhibit a number of key reactions in primary metabolism which, in turn, would cause a reduction in the activity of secondary pathways linked to toxin production.

(iv) Induction ${ }^{32}$ : The addition of certain primary metabolites (termed effectors) could induce the formation of enzymes in pathways leading to toxin production. This effect would be aside from any function the effectors might have as precursors of the toxins.

(v) Chelation theory ${ }^{33,34}$ : This theory accounts for the increased activity of the metal complexes. Chelation reduces the polarity of the metal atom, mainly because of partial sharing of its positive charge with the donor groups and possible $\pi$ electron delocalisation within the whole chelate ring. The chelation increases the lipophilic nature of the central atom, which subsequently favours its permeation through the lipid layer of the cell membrane.

(vi) Penetration of cell wall ${ }^{35}$ : Chitinases and a another compound, $\beta$-1,3-glucanase, defense system of the plants, hydrolyze fungal cell walls and inhibit the rapid growth of fungal pathogens.

The results of fungicidal and bactericidal screening of the silicon complexes against some pathogenic fungi and bacteria are recorded in Tables 5 and 6 . The results show that the activity is enhanced on undergoing chelation. It is a well-known fact that the concentration plays a vital role in increasing the degree of inhibition. Hence as the concentration increases, the activity also increases.
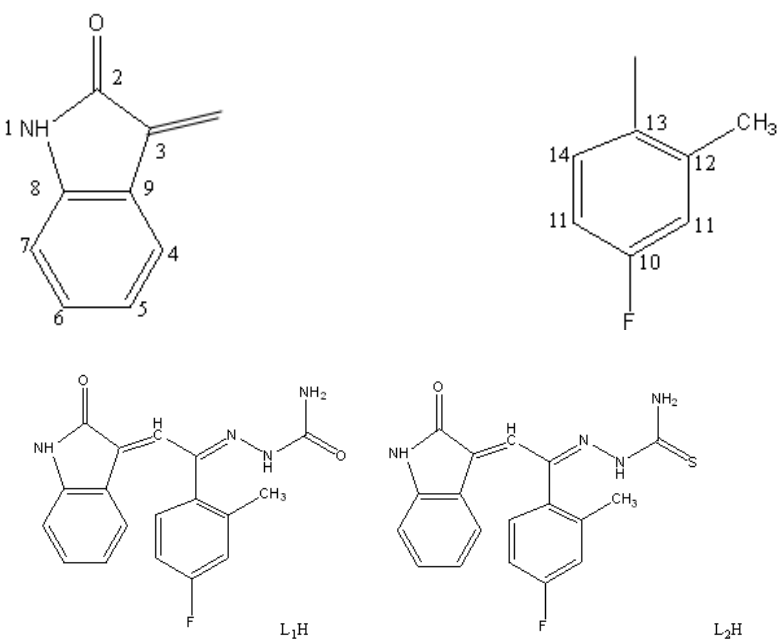

Figure 1. Structures of the ligands

\section{References}

[1] M. G. Voronkov, R. G. Mirskov, A. T. Platonova, G. V. Kuznetsova, E. E. Kuznetsova, T. A. Pushechkina, L. V. Orgil"yanova, T. I. Malkova, O. I. Minkina, L. T. Moskvitina, Pharm. Chem. J. 1979, 13: (3), 265.

[2] M. Kidwai, B. Dave, P. Misra, R.K. Saxena, M. Singh, Inorg. Chem. Commun. 2000, 3: (9), 465.

[3] G. Bergamaschi, A. Bonardi, E. Leporati, P. Mazza, P. Pelagatti, C. Pelizzi, G. Pelizzi, A. M. C. Rodriguez, F. Zani, J. Inorg. Biochem. 1997, 68: (4), 295.

[4] M. Nath , R. Yadav, Bull. Chem. Soc. Jpn. 1997, 70: (6), 1331 .

[5] G. Marcel, Coordin. Chem. Rev. 1996, 151, 41.

[6] B. B. Federica, V. Maurizio, S. Fabio, S. Gennaro, F. Anna, B. Cristina, N. Federica, A. Angela, Colloq. Inse. 2002, 13: (6), 599

[7] J. J. Bonire, G. A. Ayoko, P.F. Olurinola, J.O. Ehinmidu, N.S.N. Jalil, A. A. Omachi, Met.-Based Drugs 1998, 5: (4), 233. 
[8] E. Arkis, D. Balköse, Polym. Degrad. Stabil. 2005, 88: (1), 46.

[9] J. Xu, C. Zhang, H. Qu, C. Tian, J. Appl. Polym. Sci. 2005, 98: (3), 1469.

[10] M.D. Kishore, D. Kumar, J. Coord. Chem. 2011, 64: (12), 2130.

[11] R. Garg, M.K. Saini, N. Fahmi, R.V. Singh, Indian J. Chem. 2005, 44A, 2433.

[12] R.V. Singh, M. Jain, C.N. Deshmukh, Appl. Organomet. Chem. 2005, 19, 904.

[13] H. Masood, S. Ali, M. Mazhar, S. Shahzadi, K. Shahid, Turk J. Chem. 2004, 28, 75.

[14] J. Otera, J. Organomet. Chem. 1981, 221, 57.

[15] R. Kapoor, A. Gupta, P. Kapoor, P. Venugopalan, Appl. Organomet. Chem. 2003, 17: (8), 607.

[16] G. Casella, F. Ferrante, G. Saielli, Inorg. Chem. 2008, 47: (11), 4796.

[17] T. Nishida, I. Wahlberg, C.R. Enzell, Magn. Reson. Chem. 1977, 9: (4), 203.

[18] J.D. Mao, K. Schmidt-Rohr, Els. 2004, 26: (1), 36.

[19] A.A. Panasenko, A.F. Caprosh, O.M. Radul, M.A. Rekhter, Russ. Chem. B+. 1994, 43: (1), 60.

[20] A. Jain, S. Saxena, A. K. Rai, P. N. Saxena, Bioinorg. Chem. Appl. 2006, 2006, 60140.

[21] R. C. Santos, J.R. Maia, S. da, A. Abras, C. A. L. Filgueiras, Hyperfine Interact. 2002, 142, 495.
[22] A. Jain, S. Saxena, R. Bohra, A.K. Rai, Main Group Met. Chem. 1995, 18, 139.

[23] Gaur S, Fahmi N, Agarwal M, Singh RV, Appl. Organomet. Chem. 2007; 21: 89 .

[24] K.D. Chenault, H.K. Melouk, M.E. Payton, Crop Sci. 2005, 45,511 .

[25] L.M. Iyer, S.P. Kumpatla, M.B. Chandrasekharan, T.C. Hall, Plant Mol. Biol. 2000, 30, 351.

[26] J.A. Lucas, Plant Pathol. 1997, 3, 52.

[27] K.D. Chenault, J.A. Burns, H.A. Melouk, M.E. Payton, Peanut Sci. 2002, 29, 89.

[28] M. Zhang, H.K. Melouk, K.D. Chenault, Z. El. Rassi, J. Agr. Food Chem. 2001, 49, 5265.

[29] N. Gandhi, R. Jain, N.K. Kaushik, Thermochim. Acta 1996, 282/283, 501 .

[30] M. Jain, S. Gaur, S.C. Diwedi, S.C. Joshi, R.V. Singh, A. Bansal, 2004, 179: (8), 151.

[31] M.J. Leel, D.W. Gong, B.F. Burkey, S.K. Fried, AM J. Physiol. 2012, 44: (2), 141.

[32] M.S. Baptista, M.T. Vasconcelos, Inform. Healthcare, 2006, 32: (3), 127.

[33] P.K. Panchal, H.M. Parekh, P.B. Pansuriya, M.N. Patel, Inform. Healthcare, 2006, 21: (2), 203.

[34] M. Jain, S. Manju, R.V. Singh, Appl. Organomet. Chem. 2004, 18: (9), 471.

[35] C.E. Simpson, O.D. Smith, H.A. Melouk, Crop Sci. 2000, $40,859$. 